\title{
Spectrum of Hepatits B Infection Among Patients Attending Liver Unit in Nepalgunj Medical College - Kohalpur
}

\author{
Khadka $D^{1}$, KC S$^{2}$, Karki N ${ }^{3}$, Khadka S ${ }^{4}$, Regmi K
}

\begin{abstract}
Introduction: Hepatitis B infection is a global problem. Hepatitis B virus (HBV) infection related liver disease is also not an uncommon problem in our country too. Reports regarding pattern of chronic HBV infection are also lacking. The aim of the present study was to determine the spectrum of chronic HBV infection among patients attending the liver clinic in a tertiary care center. Method: A hospital based descriptive cross-sectional study was carried out in Liver unit of Nepalgunj Medical College, Kohalpur, from April 2018 to November 2018. All patients with HBsAg positive were further tested for $\mathrm{HBeAg}, \mathrm{HBeAb}, \mathrm{HBV}$ DNA quantitative and liver function test. Ultrasound examination was advised for any evidence of chronic liver disease. Staging was done according to viral serology, liver biochemistry and ultrasonography of liver. Results: Total patients enrolled were 119. Majority of patents were in between 30-60 years (51.3\%) with male predominance $59.7 \%$. Most of patients were in the stage of HBeAg negative chronic infection $66.4 \%$ with normal transaminase and HBV DNA $<2000 \mathrm{IU} / \mathrm{ML}$. Majority of patients having unknown source of infection $90.8 \%$. Incidental detection (67.2\%) was common mode of detection. Conclusions: Majority of patients were in HBeAg negative chronic hepatitis B infection phase with normal transaminase and low HBV DNA not requiring treatment.
\end{abstract}

\section{Key words: Chronic hepatitis B, Hepatitis Be antigen, Hepatitis B virus, Hepatitis B virus DNA}

\section{INTRODUCTION}

Hepatitis B infection which is caused by the hepatitis B virus (HBV), an enveloped DNA virus remains a major global public health problem with significant morbidity and mortality ${ }^{1,2,3}$. Approximately 240 million people are chronic HBV surface antigen (HBsAg) carriers, with a large regional variation of HBsAg positive patients between low $(<2 \%)$ and high $(>8 \%)$ endemicity levels ${ }^{4}$. Among Asian countries, Nepal has the lowest prevalence of hepatitis B virus (HBV) infection with an HBsAg carrier rate of $0.9 \%{ }^{5}$. Carriers of HBV areat increased risk of developing complications like cirrhosis, hepatic decompensation, and hepatocellular carcinoma $(\mathrm{HCC})^{6}$.

The natural course of chronic HBV infection is determinedby the interplay between virus replication and the host immuneresponse and final outcome of $\mathrm{CHB}$ infection depends on the stage of $\mathrm{CHB}$ infection, severity of liver disease. So early recognition of disease condition is very crucial for prognosis. The aim of present study was to assess the spectrum of $\mathrm{CHB}$ infection among patients attending tertiary care center, also this kind of study was lacking in this region too.

\footnotetext{
1. Dr. Dipendra Khadka

2. Dr. Sudhamshu KC

3. Dr. Niyanta Karki

4. Dr. Sandip Khadka

5. Dr. Kiran Regmi
}

Address for correspondence:

Dr. Dipendra Khadka

Department of Medicine

Nepalgunj Medical College \& Teaching Hospital

Kohalpur, Banke, Nepal

Email: khadkadipendra39@gmail.com

\section{METHODOLOGY}

This hospital based descriptive cross-sectional study was carried out in Liver unit of Nepalgunj Medical College, Teaching Hospital, Kohalpur from April 2018 to November 2018. Ethical approval was taken from Institutional Review Board (IRB), NGMC and written informed consent was taken from each patient. All patients attending liver OPD with liver related disease found positive for $\mathrm{HbsAg}$ during screening, referred from other departments and other centers with $\mathrm{HbsAg}$ positive were enrolled in the study. HbsAg was further confirmed by ELISA. Anti HCV Ab and HIV was also done for co-infection as mode of transmission is similar in all groups. Further evaluation for those found to beHBsAg positive included baseline liver function tests, hepatitis Be antigen ( $\mathrm{HBeAg})$, anti-HBeAband HBV DNA quantification. Anti-HBclgG, Anti-HBclgM, Anti $\mathrm{HbsAb}$ were done when considered appropriate. Ultrasound examination was adviced for any evidence of chronic liver disease and it's squeal like ascites, hepatocellular carcinoma (HCC) or portal vein thrombosis. Patients positive for antiHBclgM were followed for a further 6 months for viral clearance. Alanineaminotransferase (ALT) levels $>40 \mathrm{U} / \mathrm{L}$ were considered as elevated for both men and women. Patient information included age, gender, date of detection and duration of HBsAg positivity, family history of liver disease including HCC, past history of tattoo, blood transfusion, jaundice, and surgery were noted. All family members including children of index $\mathrm{HBsAg}$ positive patients were advised for HBsAg screening and further evaluation, if found positive. HBsAg negative patients were advised for vaccination against HBV infection. Based on the viral profile and transaminase levels and ultrasound findings, patients were categorized as $\mathrm{HBeAg}$ positive chronic infection, $\mathrm{HBeAg}$ positive chronic hepatitis, $\mathrm{HBeAg}$ negative chronic infection, $\mathrm{HBeAg}$ negative chronic hepatitis and acute hepatitis B. ${ }^{7}$ Data 
collected in structured proforma were entered in Microsoft Excel 2007 and statistical analysis was done with SPSS 20 software.

\section{RESULTS}

Total patients enrolled in the study were 119. Minimum age was 3 year and maximum age was 80 year. Majority of patients were in the age group of $30-60$ years $51.3 \%$ (61) with male predominance $59.7 \%$ (71) as shown in table I.

\begin{tabular}{|c|l|c|c|}
\hline \multicolumn{2}{|l|}{ Variable } & Number & Percentage \\
\hline \multirow{4}{*}{ Age (Years) } & $<10$ & 3 & $2.5 \%$ \\
\cline { 2 - 4 } & $10-30$ & 45 & $37.8 \%$ \\
\cline { 2 - 4 } & $30-60$ & 61 & $51.3 \%$ \\
\cline { 2 - 4 } & $>60$ & 10 & $8.4 \%$ \\
\hline
\end{tabular}

Mean \pm SD age: $36.47 \pm 15.67$, Minimum age: 3 years \& Maximum age: 82 years

\begin{tabular}{|l|l|c|c|}
\hline Gender & Female & 48 & $40.3 \%$ \\
\cline { 2 - 4 } & Male & 71 & $59.7 \%$ \\
\hline \multirow{4}{*}{ Districts } & Achham & 4 & $3.4 \%$ \\
\cline { 2 - 4 } & Bajhang & 5 & $4.2 \%$ \\
\cline { 2 - 4 } & Banke & 18 & $15.1 \%$ \\
\cline { 2 - 4 } & Bardia & 6 & $5.0 \%$ \\
\cline { 2 - 4 } & Dadeldhura & 1 & $0.8 \%$ \\
\cline { 2 - 4 } & Dailekh & 4 & $3.4 \%$ \\
\cline { 2 - 4 } & Dang & 11 & $9.2 \%$ \\
\cline { 2 - 4 } & Darchula & 2 & $1.7 \%$ \\
\cline { 2 - 4 } & Dolpa & 1 & $0.8 \%$ \\
\cline { 2 - 4 } & Doti & 4 & $3.4 \%$ \\
\cline { 2 - 4 } & Jagarkot & 6 & $5.0 \%$ \\
\cline { 2 - 4 } & Kailali & 28 & $23.5 \%$ \\
\cline { 2 - 4 } & Kalikot & 8 & $6.7 \%$ \\
\cline { 2 - 4 } & Kanchanpur & 6 & $5.0 \%$ \\
\cline { 2 - 4 } & Rolpa & 1 & $0.8 \%$ \\
\cline { 2 - 4 } & Rukum & 4 & $3.4 \%$ \\
\cline { 2 - 4 } & Salyan & 2 & $1.7 \%$ \\
\cline { 2 - 4 } & Sunsari & 1 & $0.8 \%$ \\
\cline { 2 - 4 } & Surkhet & 7 & $5.9 \%$ \\
\hline
\end{tabular}

Table I: Showing demographic characters of patients

Among total enrolled patients majority were $\mathrm{HbeAb}$ positive $90.8 \%$ (108), Anti HBclgM positive found in 5 patients. HBV DNA was done only by 107 patients. Majority of patients were having value $<2000 \mathrm{iu} / \mathrm{ml}$. 52.3\% (56). One patient was co- infected with Hepatitis C infection. T

able III showing possible mode of transmission of HBV infection. Majority of patients having unknown source of infection $90.8 \%$ (101). Majority of patients were detected having HBsAg positive incidentally during screening for other purposes as shown in table IV.

\begin{tabular}{|l|c|c|c|}
\hline Variable & & Number & Percentage \\
\hline HbeAg & Positive & 11 & $9.2 \%$ \\
\hline HbeAb & Positive & 108 & $90.8 \%$ \\
\hline Anti HBclgM & Positive & 5 & $4.2 \%$ \\
\hline \multirow{2}{*}{$\begin{array}{l}\text { HBV DNA (IU/ML) } \\
\text { n=107) }\end{array}$} & $<2000$ & 56 & $52.3 \%$ \\
\cline { 2 - 4 } & $2000-20000$ & 23 & $21.5 \%$ \\
\cline { 2 - 4 } & $>20000$ & 28 & $26.2 \%$ \\
\hline Anti HCV Ab & Positive & 1 & $0.8 \%$ \\
\hline HIV & Negative & 119 & $100.0 \%$ \\
\hline
\end{tabular}

Table II: Showing serological profile

\begin{tabular}{|l|c|c|}
\hline Variable & Number & Percentage \\
\hline Vertical & 8 & $6.7 \%$ \\
\hline Post blood transfusion & 0 & $0.0 \%$ \\
\hline IDU & 0 & $0.0 \%$ \\
\hline Hemodialysis & 0 & $0.0 \%$ \\
\hline Sexual & 1 & $.8 \%$ \\
\hline Surgery & 0 & $0.0 \%$ \\
\hline Family histroy & 9 & $7.6 \%$ \\
\hline Unknown & 101 & $90.8 \%$ \\
\hline
\end{tabular}

IDU-intravenous drug user

Table III: Possible mode of transmission

\begin{tabular}{|l|c|c|}
\hline Variable & Number & Percentage \\
\hline Screening during pregnancy & 9 & $7.6 \%$ \\
\hline Screening during surgery & 0 & $0.0 \%$ \\
\hline Screening during blood transfusion & 0 & $0.0 \%$ \\
\hline Incidental detection & 80 & $67.2 \%$ \\
\hline Symptomatic & 30 & $25.2 \%$ \\
\hline
\end{tabular}

Table IV: Mode of detection

\begin{tabular}{|l|c|c|}
\hline Variable & Number & Percentage \\
\hline Acute HBV Infection & 4 & $3.4 \%$ \\
\hline HBe Ag Negative chronic hepatitis & 32 & $26.9 \%$ \\
\hline HBeAg Negative chronic Infection & 79 & $66.4 \%$ \\
\hline HBeAg Positive chronic Infection & 4 & $3.4 \%$ \\
\hline
\end{tabular}

Table V: Stage of HBV Infection 


\begin{tabular}{|l|c|c|c|c|c|}
\hline Variables & $\begin{array}{c}\text { Acute HBV } \\
\text { Infection } \\
\text { (Mean } \pm \text { SD) }\end{array}$ & $\begin{array}{c}\text { HBe Ag } \\
\text { Negative chronic } \\
\text { hepatitis } \\
\text { (Mean } \pm \text { SD) }\end{array}$ & $\begin{array}{c}\text { HBeAg } \\
\text { Negative chronic } \\
\text { Infection } \\
\text { (Mean } \pm \text { SD) }\end{array}$ & $\begin{array}{c}\text { HBeAg } \\
\text { Positive chronic } \\
\text { Infection } \\
\text { (Mean } \pm \text { SD) }\end{array}$ & *P-Value \\
\hline Age (Year) & $31.25 \pm 6.29$ & $50.72 \pm 13.66$ & $31.99 \pm 12.93$ & $16.25 \pm 7.8$ & $<0.001$ \\
\hline Bilirubin(mg/dl) & $10.53 \pm 2.16$ & $3.16 \pm 1.41$ & $1.35 \pm 0.46$ & $1.1 \pm 0.14$ & $<0.001$ \\
\hline ALT (u/l) & $835.75 \pm 399.67$ & $89.38 \pm 28.1$ & $37.33 \pm 6.9$ & $33.5 \pm 0.58$ & $<0.001$ \\
\hline $\begin{array}{l}\text { HBV DNA } \\
\text { (iu/ml)(n=103) }\end{array}$ & $202775 \pm 122384.92$ & $61475.84 \pm 96038.1$ & $1488.41 \pm 3626.87$ & $113775 \pm 4912.82$ & $<0.001$ \\
\hline
\end{tabular}

Table VI: Relation between different stage with age, bilirubin level, and ALT and DNA level

There was significant relation between different stages of HBV infection in relation to age, serum bilirubin level, ALT level and HBV DNA level as shown in table VI.

\section{DISCUSSION}

In present study $\mathrm{CHB}$ infection was more common in male gender $59.7 \%(71)$ as compared to female $40.3 \%$ (48). Majority of patients were in the age group of $30-60$ years $51.3 \%$ (61). Balasubramanian et al. also reported male preponderance in their study with mean age of men was 40 years and of women was 34 years $^{8}$. Shrestha SM et al, in their prevalence study also reported male predominance but highest prevalence of $\mathrm{CHB}$ infection among age groups of 6-15 years compared to 30-60 years in our study. The difference in age group might be explained as our was hospital based study, serological test for $\mathrm{HbsAg}$ only done when indicated as compared to their community based prevalence study.

Our study showed serological profile shows $\mathrm{HBeAg}$ negative group was more common $90.8 \%$ (108) than HBeAg positive group $9.2 \%$ (11). Lahiri et al, also reported majority $89.5 \%$ (384) were $\mathrm{HBeAg}$ negative, while $10.5 \%$ (45) were $\mathrm{HBeAg}$ positive in their study ${ }^{9}$. Similar results were also reported by Amarapurkar et al, 61\% (222) HBeAgnegative and 39 \% (141)

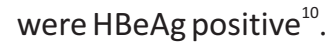

In our study, one patient was found to be co-infected with both hepatitis B and hepatitis Cviral infection. Precise study is limited regarding co-infected patients. One study by Desikan et al, from India reported $1.89 \%$ co-infected with both virus ${ }^{11}$. Hepatitis B virus (HBV) and hepatitis C virus (HCV) have several important similarities including worldwide distribution, hepato-tropism, similar modes of transmission and the ability to induce chronic infection that may lead to liver cirrhosis and hepatocellular carcinoma. Co-infection with both HBV and HCV would be expected to be linked with higher morbidity as well as mortality and impact healthcare resource utilization.

In present study, possible mode of transmission was unknown among majority of patients $90.8 \%$ (101). Vertical transmission was reported in $6.7 \%$ (8). Shrestha SM alsoreported perinatal transmission is rare in Nepalese population ${ }^{12}$. Another study by Shrestha SM et al, reported horizontal spread was more common among young adults ${ }^{13}$. In a study conducted by Khokhar et al, in Pakisthan also reported intramuscular injections and surgery were noted to be frequent risk factors ${ }^{14}$.

In our study most of the patients were detected incidentally during screening for other purposes $67.2 \%(80)$. These groups of patients are mostly asymptomatic and study also revealed that asymptomatic subjects with incidental detection of hepatitis B surface antigen (HBsAg), usually have a benign nonprogressive cours $\mathrm{e}^{15}$. In our study majority of patients were in HBeAg negative chronic infection $66.4 \%$ (s79) not requiring treatment, similar observation was also reported by Balasubramanian et al. ${ }^{8}$ In this group of patients were having normal bilirubin, normal ALT and low or undetected HBV DNA level comparable to other study also. So in this group of patients, no need of antiviral therapy unless significant fibrosis detected by liver biopsy or other non-invasive tests.

\section{LIMITATION}

In our study, HBV DNA quantitative analysis was not done by all patients and accurate assessment of liver fibrosis which is measured by liver biopsy and or transient elastography (Fibro Scan) is not done in our study.

\section{CONCLUSION}

A significant number of HBsAg-positive patients belong to HBeAg negative chronic hepatitis B infection phase, not requiring treatment.

\section{REFERENCES}

1. European Association for the Study of the Liver. EASL clinical practice guidelines: Management of chronic hepatitis B virus infection. J Hepatol 2012;57: 167-85.

2. Schweitzer A, Horn J, Mikolajczyk RT, Krause G, Ott JJ. Estimations of worldwide prevalence of chronic hepatitis $B$ virus infection: $A$ systematic review of data published between 1965 and 2013. Lancet.2015;386:1546-55.

3. Lozano R, Naghavi M, Foreman K, Lim S, Shibuya K, Aboyans V, et al. Global and regional mortality from 235 causes of death for 20 age groups in 1990 and 2010: A systematic analysis. 
4. Ott JJ, Stevens GA, Groeger J, Wiersma ST. Global epidemiology of hepatitis B virus infection: New estimates of age-specific HBsAgsero prevalence and endemicity. Vaccine 2012;30:2212-19.

5. ShresthaSM, Shrestha S.Chronic hepatitis B in Nepal: An Asian country with low prevalence of HBV Infection.Tropical Gastroenterology 2012; 33(2):95-101

6. Beasley RP. Hepatitis B virus. The major etiology of hepatocellular carcinoma. Cancer 1988;61(10):1942-56.

7. European Association for the Study of the Liver. EASL 2017 Clinical Practice Guidelines on the management of hepatitis B virus infection. J Hepatol. 2017 Aug;67(2):370-98.

8. Balasubramanian S, Velusamy A,Krishnan A, Venkatraman J. Spectrum of hepatitis B infectionin Southern India: A crosssectional analysis. Hep B Annual2012;9:4-15.

9. Lahiri KK, Sahni AK, Gupta RM, Duhan SD, Kapila K, Jena BJ.Hepatitis B e Antigen Negative Chronic Hepatitis in IndianPatients : A Reality.MJAFI 2007; 63 : 318-21

10. Amarapurkar DN, Baijal R, Kulshrestha PP, Agal S, Chakraborty $M R$, Pramanik SS. Profile of hepatitis $B$ e antigen-negative chronic hepatitis B.Indian J Gastroenterol. 2002 May Jun; 21(3):99-101.

11. Desikan $P$, Khan Z. Prevalence of hepatitis $B$ and hepatitis $C$ virus co-infection in India: A systematic review and metaanalysis. Indian J Med Microbiol. 2017 Jul-Sep;35(3):332-39.

12. Shrestha SM. Incidence of HBsAg carrier rate in pregnant women in Kathmandu. J Inst Med. 1987;71-6

13. Shrestha SM, Shrestha IN, Maharjan KG. Family clustering of HBV infection in the household of persistent HBsAg carriers: spread of HBV by horizontal transmission. J Inst Med. 1991;13:319-26.

14._KhokharN, _Gill ML Serological profile of incidentally detected asymptomatic HBsAg positive subjects (IDAHS). Journal of the College of Physicians and Surgeons--Pakistan : JCPSP [01 Apr 2004, 14(4):208-10.

15. Hoofnagle JH, Shafritz DA, Popper H. Chronic type B hepatitis and the "healthy" HBsAg carrier state. Hepatology 1987; 7:758-63. 